\title{
Weed Management in Home Lawns ${ }^{1}$
}

\section{J.Bryan Unruh, Barry Brecke, Laurie E. Trenholm²}

Weeds can simply be defined as unwanted plants or plants growing out of place. The proper identification of weeds and some understanding of how and why weeds are present in a lawn are important in selecting the best control strategy. Knowledge of whether or not weeds were previously present in a particular area will also help the homeowner prepare for control procedures in the future. Weed control should be a carefully planned and coordinated program instead of a hit-or-miss operation.

\section{Types of Weeds}

Knowledge of weed growth habit is important for developing an effective weed management program.

\section{Broadleaves}

Broadleaves, or dicotyledonous plants, have two cotyledons (seed leaves) when the weed seed germinates. Their true leaves have net-like veins and usually have showy flowers. Examples include clovers, lespedeza, plantain, henbit, chickweed, Florida pusley, beggarweed, matchweed, and many others.

\section{Grasses}

Grasses are monocotyledonous plants that have only one cotyledon, or seed leaf, present when seedlings emerge from the soil. Grasses have hollow, rounded stems with nodes (joints) and parallel veins in their true leaves. Examples include crabgrass, goosegrass, crowfootgrass, dallisgrass, bullgrass, annual bluegrass, alexandergrass, cogongrass, torpedograss, and smutgrass.

\section{Sedges/Rushes}

Sedges have stems that are triangular in shape and solid, while rush stems are round. Both sedges and rushes favor a moist habitat. Economically important examples include yellow and purple nutsedge, globe, Texas, annual, and water sedge, perennial kyllinga, as well as path and beak rush.

1. This document is ENH884, one of a series of the Environmental Horticulture Department, Florida Cooperative Extension Service, Institute of Food and Agricultural Sciences, University of Florida. Original publication date March 3, 2003. Visit the EDIS Web Site at http://edis.ifas.ufl.edu.

2. Barry J. Brecke, Professor and Associate Center Director, Weed Scientist, Agronomy Department, West Florida Research and Education Center, Institute of Food and Agricultural Sciences, University of Florida, Jay, Florida 32565.

Bryan Unruh, Associate Professor, Turf Specialist, Environmental Horticulture Department, Cooperative Extension Service, Institute of Food and Agricultural Sciences, University of Florida, Jay, Florida 32565.

Laurie E. Trenholm, Assistant Professor, Extension Turgrass Specialist, Environmental Horticulture Department, Institute of Food and Agricultural Sciences, University of Florida, Gainesville, Florida.

The use of trade names in this publication is solely for the purpose of providing specific information. UF/IFAS does not guarantee or warranty the products named, and references to them in this publication does not signify our approval to the exclusion of other products of suitable composition.

The Institute of Food and Agricultural Sciences is an equal opportunity/affirmative action employer authorized to provide research, educational information and other services only to individuals and institutions that function without regard to race, color, sex, age, handicap, or national origin. For information on obtaining other extension publications, contact your county Cooperative Extension Service office. Florida Cooperative Extension Service/Institute of Food and Agricultural Sciences/University of Florida/Christine Taylor Waddill, Dean. 


\section{Proper Management First}

The first and best method of weed control begins with proper management practices that encourage a dense, thriving turf. Healthy turf shades the soil so sunlight can't reach weed seeds that are ready to germinate. A thick turf also minimizes the physical space available for weeds to become established. There are several management practices that will promote a healthy, dense grass.

\section{Proper Turfgrass Selection}

The first management decision is selection of the best turf species or variety for a particular area. For example, heavily shaded areas will support only a few turfgrass species. Growing bermudagrass or bahiagrass in shaded areas will result in thin, weak turf that is very susceptible to weed invasion. Alternate grass choices for shady conditions include certain cultivars of St. Augustinegrass, zoysiagrass, and, to a lesser degree, centipedegrass.

\section{Proper Cultural Practices}

Proper fertilization, watering, mowing, and control of other pests are required to produce a dense turf that will prevent weed infestation. If turf is overor underwatered, over- or underfertilized, or mowed too low or too infrequently, the turf will be weakened and unable to compete with weeds. The use of mowers with unsharpened blades results in damaged areas and increases the time needed for turf recovery, allowing for weed invasion. It is very important to understand that weeds don't create a void, they fill a void.

\section{Traffic Control}

Turf damaged by foot or vehicle traffic invites weeds. Turf growing in areas compacted by excess traffic, especially when the soil is water-saturated, cannot extract oxygen as well as turf under noncompacted conditions. Goosegrass, annual bluegrass, and certain sedges are weeds that grow well in compacted and/or continuously wet soil. The first step to managing weeds in such a situation is to alleviate soil compaction and/or the saturated condition.

\section{Other Pest Control}

Turf damaged by pests such as insects or diseases does not always recuperate quickly enough to out-compete germinating weeds. For example, tunneling from mole crickets disrupts the soil surface, enabling weeds to germinate and become established. Other insects and diseases can severely damage turf, resulting in bare areas. These open areas are usually slow to recover, thus enabling weeds to become established. High nematode populations also thin the turf and make it less able to recuperate from environmental stresses. Weeds that often become established in nematode-infested soil include spotted spurge and Florida pusley.

\section{Sanitation}

It is extremely important to prevent the introduction of weeds into lawn areas. If one can prevent weed establishment, there will be no need for control practices. Areas adjacent to fine turf that are hard to mow, such as fencerows or ditch banks, often serve as a source of weed seed that infests the nearby turf. These areas should receive weed management attention.

Another good practice is to wash mowers and trimmers used in weed-infested areas before mowing or trimming in weed-free areas. Similarly, rototillers should be thoroughly cleaned before and after use to minimize dispersal of weed seeds found in the soil. Yard clippings that contain weeds should be properly disposed of or composted to reduce the possibility of unwanted contamination.

It is important to use weed-free soil during construction or renovation. To minimize weed invasion during planting, use only certified seed or weed-free sod. It is not unreasonable to request a tour of the sod farm where the sod will be purchased in order to inspect the quality of the grass.

\section{Weed Biology and Control}

Weeds complete their life cycles in one growing season (annuals), two growing seasons (biennials), or three or more years (perennials). Annuals that complete their life cycles between spring and fall are generally referred to as summer annuals, and those 
that complete their life cycles between fall and spring are winter annuals. Summer annual grasses, as a class, are generally the most troublesome weeds in turf. An excellent weed identification guide, Weeds of

Southern Turfgrasses (SP 79) can be obtained through your local county cooperation extension office.

\section{Methods}

As previously stated, it is essential that turf be properly maintained in order to minimize weed invasion. If weeds become established, several methods of control are available.

Mowing - If proper mowing height and frequency are maintained, many annual weeds will be eliminated. Mowing prior to weed seedhead formation will also reduce weed seed reserves. Some weeds, however, will readily establish below the optimum mowing height for the turfgrass. Control of these weeds will require additional control methods.

Hand Pulling - If only a few weeds are present, it is easier and less time-consuming to physically remove the plant. If weeds are a major problem, however, other alternatives should be considered.

Mulch - Smothering with a mulch of nonliving material to exclude light is effective in certain areas, such as flowerbeds, footpaths, or nurseries, where turf is not grown. Materials used in such a manner include straw, sawdust, hay, wood chips, and plastic film. Care must be taken to prevent mowing accidents due to movement of these materials into a maintained turf area. To be effective, a minimum of 2 inches is required when using natural mulch materials.

Synthetic mats impregnated with herbicides are an alternative available for use in the landscape. These provide long-term weed control when properly used, but care must be taken to keep desirable plant roots from encountering these layers.

Herbicides - An herbicide is any chemical that injures or kills a plant. Herbicides are safe and effective if product label instructions are followed. For best results, herbicides should be applied at the proper time, at the labeled rate, using the appropriate application method. Timing of postemergence herbicide application during the plant's growth cycle is important. For example, weeds not treated before seedhead formation are harder to control and are able to deposit new seeds for future problems. Herbicides are classified based on how and when they control weeds.

\section{Herbicide Types}

Selective - A selective herbicide controls certain plant species without seriously affecting the growth of other plant species. The majority of herbicides used are selective herbicides.

Nonselective - Nonselective herbicides control green plants regardless of species. These are generally used to kill all plants, such as in the renovation or establishment of a new turf area, for spot treatment, or as a trimming material along sidewalks, etc. Glyphosate (Roundup ${ }^{\circledR}$ ), Glufosinate $\left(\right.$ Finale $\left.^{\circledR}\right)$, and Diquat $\left(\right.$ Reward $\left.^{\circledR}\right)$ are examples of nonselective herbicides. are examples of nonselective herbicides.

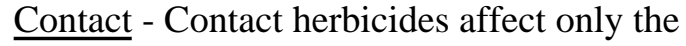
portion of green plant tissue that is contacted by the herbicide spray. These herbicides are not translocated or moved in the vascular system of plants. Therefore, these will not kill underground plant parts, such as rhizomes or tubers. Contact herbicides often require repeat applications to kill regrowth from these underground plant parts. Examples of contact herbicides include the organic arsenicals (MSMA, DSMA), bentazon (Basagran ${ }^{\circledR}$ ), glufosinate $\left(\right.$ Finale $\left.^{\circledR}\right)$, and diquat $\left(\right.$ Reward $\left.^{\circledR}\right)$.

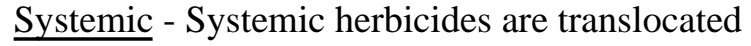
in the plant's vascular system. The vascular system transports the nutrients and water necessary for normal growth and development. Systemic herbicides generally are slower acting and kill plants, over a period of days. Examples of systemic herbicides include glyphosate (Roundup ${ }^{\circledR}$ ), 2,4--Dichlorophenoxyacetic acid $\left(2,4-\mathrm{D}^{\circledR}\right)$, dicamba $\left(\right.$ Banvel $^{\circledR}$ ), imazaquin (Image ${ }^{\circledR}$ ), and sethoxydim $\left(\right.$ Vantage $\left.^{\circledR}\right)$.

\section{Timing of Application}

Herbicides can also be classified by application timing. 
Preemergence - Preemergence herbicides form the basis for a chemical weed control program in turfgrass and are used primarily to control annual grasses (e.g., crabgrass, goosegrass, and annual bluegrass) and certain annual broadleaf weeds (e.g., common chickweed, henbit, and lawn burweed). Preemergence herbicides are applied before weed seed germination. Knowledge of weed life cycles is important, especially when herbicide application is timed to attempt preemergence control. If the chemical is applied after weed emergence, preemergence herbicides will have little or no effect. This narrow window of application timing is a potential disadvantage for many lawn care companies and homeowners, who often wait until too late in the spring to apply the preemergence herbicide. A general rule of thumb for preemergence herbicide application is to apply February 1 in south Florida, Feb. 15 in central Florida, and March 1 in north Florida (when day temperatures reach $65^{\circ}$ to $70^{\circ} \mathrm{F}$ for four or five consecutive days). These application timings generally coincide with blooming of landscape plants such as azalea and dogwood. If goosegrass is the primary weed species expected, perform preemergence application two to three weeks later than these suggested application dates, since goosegrass germinates later than most summer annual grasses.

For preemergence control of winter annual weeds such as annual bluegrass, apply an herbicide when nighttime temperatures drop to $55^{\circ}$ to $60^{\circ} \mathrm{F}$ for several consecutive days (early October for North Florida, late October to early November for central and South Florida).

Adequate soil moisture before and after application is necessary to activate most preemergence herbicides. Preemergence herbicides are generally effective in controlling weeds from 6 to 12 weeks following application. Most herbicides begin to degrade soon after application when exposed to the environment. Therefore, to obtain season-long control, an additional application should follow 6 to 9 weeks after the initial one.

Note: On those areas where turf is to be established (including winter overseeded areas), most preemergence herbicides should not be used in the 2 to 4 months before planting. Otherwise, root damage and germination reduction of the turf seed may result.

Postemergence - Postemergence herbicides are active on emerged weeds. Normally, the younger the weed seedling, the easier it is to control. Postemergence herbicide effectiveness is reduced when the weed is under drought stress, has begun to produce seeds, or is mowed before the chemical has time to work (up to several days after application). Avoid application when these detrimental growing conditions exist.

\section{Fertilizer/Herbicide Mixtures}

Many herbicides are formulated with a granular fertilizer as the carrier. Fertilizer/herbicide mixtures enable a "weed-n-feed" treatment in the same application. These materials should only be used when a lawn has a uniform weed population. If weeds exist only on a portion of the lawn, do not apply a "weed-n-feed" product to the entire lawn. If the situation warrants the use of a "weed-n-feed" product, it is important to determine if the manufacturer's recommended rate of application supplies the amount of fertilizer needed by the turfgrass and the amount of herbicide that is required for weed control. Supplemental applications of fertilizer or herbicide may be required if the fertilizer/herbicide product does not supply enough fertilizer to meet the fertility needs of the turfgrass or the amount of herbicide needed for weed control. Turfgrass fertilizer/herbicide products should be used with caution near ornamentals. Products that contain dicamba, metsulfuron, or atrazine can be absorbed by the roots of ornamentals and cause severe injury. Do not apply products that contain these ingredients near the root zone of ornamental trees and shrubs.

\section{Adjuvants}

An adjuvant is a spray additive that enhances the performance or handling characteristic of an herbicide. Adjuvants include surfactants, crop oils, crop oil concentrates, antifoaming agents, drift control agents, and compatibility agents. Surfactants, crop oils, and crop oil concentrates should be added according to label directions, since indiscriminate use may result in severe turfgrass injury or decreased herbicide performance. These additives do not 
improve the performance of preemergence herbicides and are used only with postemergence herbicides. Surfactants, crop oils, and crop oil concentrates are not always added to postemergence herbicides. Some herbicide formulations have premixed surfactants, and no additional surfactant is necessary. The herbicide label will indicate whether a spray additive is required.

\section{Weed Control Prior to Turf Establishment}

A nonselective herbicide should be used to kill existing weeds such as bermudagrass or nutsedge before the grass is established. Only emerged plants will be controlled with this type of herbicide. For best results, apply two treatments of a nonselective herbicide fourteen days after the first application or when weed regrowth has occurred.

\section{Seeded Areas}

Do not apply preemergence herbicides before or immediately after the seeding of grasses such as common bermudagrass, bahiagrass, centipedegrass, or ryegrass (winter overseed). Due to their root-pruning or seedling-kill mode of action, preemergence herbicides may be applied only after seeded grasses have emerged and are well established. Follow label directions for proper interval between seeding and herbicide application.

\section{Sprigged, Sodded or Plugged Areas}

After planting, preemergence herbicides should not be applied until the turfgrass is established, in order to prevent damage to the turf. Postemergence herbicides, in general, should not be applied until the grass is visibly growing and spreading. Mowing will help control most broadleaf weeds until the lawn is well established. Spot spraying of weeds should be practiced until turf establishment occurs.

\section{Weed Control in Established Turf}

\section{Preemergence Weed Control}

\section{Broadleaf Weed Control - Broadleaf weeds in} turf have traditionally been controlled with members of the phenoxy herbicide family (e.g., 2,4-D, MCPA, and mecoprop) and benzoic acid herbicide family (e.g., dicamba). All are selective, systemic foliar-applied herbicides, and few broadleaf weeds, especially perennials, are controlled with just one of these materials. Therefore, these materials are commonly found in three-way herbicide mixtures such as Trimec $^{\circledR}$, Ortho's Weed-B-Gon ${ }^{\circledR}$, and Spectracide Weed Stop ${ }^{\circledR}$. Additionally, repeat applications spaced 10 to 14 days apart are usually necessary for satisfactory weed control.

Grass Weed Control - Traditionally, for tolerant turfgrass species, postemergence grass weed control has been through single and repeat applications on the organic arsenicals (e.g., MSMA), which are often found in retail products such as Fertilome ${ }^{\circledR}$ Crabgrass, Nutgrass, and Dallisgrass Killer and Drexel MSMA 6 Plus ${ }^{\circledR}$. Two to four applications spaced 7 to 10 days apart are generally required for complete control. The rate and number of applications necessary for weed control usually increase as weeds mature.

Postemergence control of grassy weeds in centipedegrass can be achieved with sethoxydim, an herbicide sold under the trade name Vantage ${ }^{\circledR}$. Additionally, atrazine-containing materials (e.g., Scotts Bonus Type $S^{\circledR}$, Hi-Yield Atrazine Weed Killer ${ }^{\circledR}$, and Ortho's Atrazine Plus ${ }^{\circledR}$ ) will provide good control of young grassy weeds with the added benefit of controlling many young broadleaf weeds.

Nutsedge Control - The predominant nutsedge (often inappropriately called nutgrass) weed species in turfgrasses are yellow and purple nutsedge. Other, more local members of the Cyperus genus include annual or water sedge, perennial and annual kyllinga, globe sedge, Texas sedge, flathead sedge, and cylindrical sedge. Path or slender rush, a member of the rush (Juncus) family, also can occur in some turf situations.

These weeds generally thrive in soils that remain wet for extended periods of time due to poor drainage or excessive irrigation. The first step in nutsedge control is therefore to correct the problem of continuously wet sites. Do not overirrigate an area and, if necessary, provide surface and subsurface drainage. 
Historically, chemical control of most sedges was with repeat applications of the organic arsenicals (e.g., MSMA). Although effective, the treatments are slow to kill the weeds and repeat applications are generally necessary, resulting in extensive damage to certain turf species.

Selective yellow nutsedge control is possible with bentazon, an herbicide found in products such as Basagran $\mathrm{T} / \mathrm{O}^{\circledR}$ and Hi-Yield Basagran ${ }^{\circledR}$. Bentazon is a contact material, meaning it will control only those portions of the weeds treated. Complete coverage of weeds is therefore necessary for greatest bentazon activity. Even with good herbicide coverage, regrowth will normally occur from the roots and tubers, and repeat applications will be necessary.

Purple nutsedge can be controlled with herbicides containing either halosulfuron or imazaquin, sold as Manage ${ }^{\circledR}$ and Image ${ }^{\circledR}$, respectively. As with bentazon, repeat applications possibly over several years - will be required to control all the underground reproductive parts or purple nutsedge.

\section{Application Procedures}

Proper rates - To avoid injury to turfgrasses and ornamentals, apply the proper rate of herbicide. Mark off 1000-square-foot areas over which to apply herbicides. Apply herbicides in 1/2 to 1 gallon of water per 1000 square feet (approximately 20 to 40 gallons per acre).

Applicators - For increased application accuracy, air pressure type sprayers are preferred over hose end type sprayers. For herbicides formulated as granulars, use a spreader and calibrate properly.

Vapor drift - Volatile vapor drift from 2,4-D ester or spray drift from 2,4-D amine, dicamba, or other phenoxy or benzoic acid compounds may damage sensitive plants such as ornamentals, trees, vegetables, or fruits. Amine forms of phenoxys can be used with greater safety near sensitive plants, but caution should still be exercised.

Equipment - Do not apply insecticides, fungicides, or other herbicides with equipment used for 2,4-D, due to the difficulty of removing this herbicide from most sprayers.

\section{General Pesticide Information}

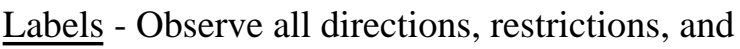
precautions on pesticide labels. It is dangerous, wasteful, and illegal to do otherwise.

Storage - Store pesticides behind locked doors in original containers with label intact, separate from seed and fertilizer.

Dosage - Use pesticides at correct dosage and intervals between applications to avoid illegal residues or injury to plants and animals.

Rinsing - Triple rinse empty containers into the spray tank. Never pour pesticides down a drain or into an area exposed to humans, animals, or water.

Disposal - Dispose of used containers in compliance with label directions so that water contamination or other hazards do not result.

Clothing - Always wear protective clothing when applying pesticides. At a minimum, wear a long-sleeved shirt, long-legged pants, rubber gloves, boots (never go barefoot or wear sandals), eye protection, and a wide-brimmed hat. Additional protective gear may be listed on the pesticide label.

Handling - Never eat, drink, or smoke when handling pesticides, and always wash with soap and water after use. 
Table 1. Herbicides for Homeowner Lawn-Weed Management

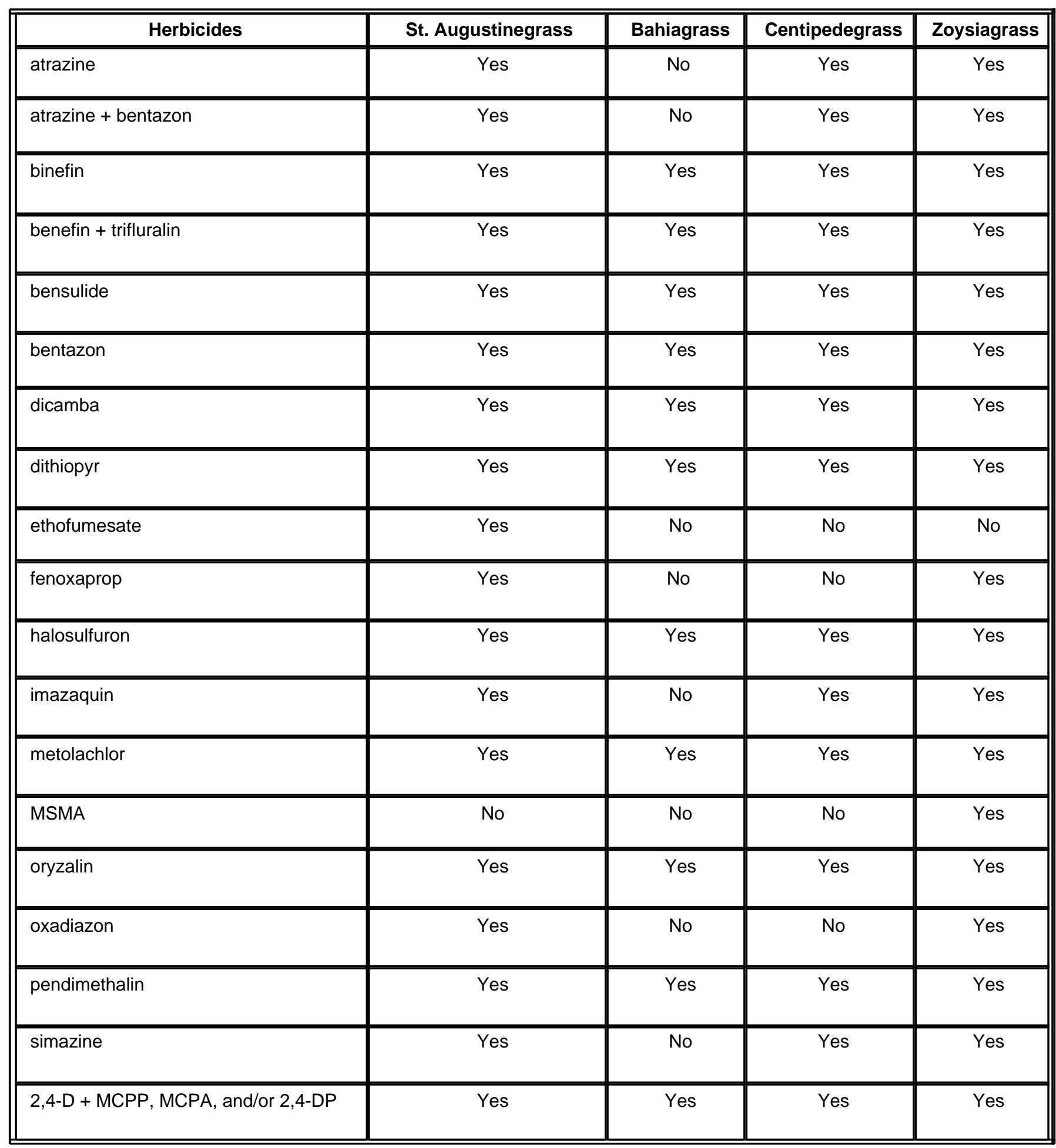


Table 2. Herbicide Common and Brand names

\begin{tabular}{|c|c|}
\hline Common Name & Brand Name \\
\hline atrazine & Many brands \\
\hline atrizine + bentazon & Prompt $^{\circledR}$ \\
\hline bentazon & $\begin{array}{l}\text { Basagran } \mathrm{T} / \mathrm{O}^{\circledR} \\
\text { Hi-Yield Basagran }^{\circledR}\end{array}$ \\
\hline benefin & Balan $^{\circledR}$ \\
\hline benefin + triflurin & Team $^{\circledR}$ \\
\hline benefin + oryzalin & $\mathrm{XL}^{\circledR}$ \\
\hline bensulide & $\begin{array}{l}\text { Betasan }^{\circledR} \\
\text { Bensumec }^{\circledR} \\
\text { Pre-San }{ }^{\circledR} \\
\text { ProTurf Weedgrass Preventer }{ }^{\circledR}\end{array}$ \\
\hline bentazon & $\begin{array}{l}\text { Basagran } \mathrm{T} / \mathrm{O}^{\circledR} \\
\text { Lescogran }^{\circledR}\end{array}$ \\
\hline CAMA & Ortho Weed-B-Gone Crabgrass Killer ${ }^{\circledR}$ \\
\hline dicamba & Banvel $^{\circledR}$ \\
\hline dithiopyr & Dimension $^{\circledR}$ \\
\hline diquat & Spectracide Systemic Grass and Weed Killer ${ }^{\circledR}$ \\
\hline ethofumesate & Progress $^{\circledR}$ \\
\hline fenoxaprop & Acclaim Extra $^{\circledR}$ \\
\hline fluazifop & $\begin{array}{l}\text { Grass Away }{ }^{\circledR} \\
\text { Grass Out }^{\circledR} \\
\text { Grass-B-Gon }^{\circledR} \\
\text { Fertilome Over-the-top Grass Killer }{ }^{\circledR}\end{array}$ \\
\hline glyphosate & $\begin{array}{l}\text { RoundUp }^{\circledR} \\
\text { Real Kill Weed and Grass } \text { Killer }^{\circledR}\end{array}$ \\
\hline halosulfuron & Manage $^{\circledR}$ \\
\hline imazaquin & Image ${ }^{\circledR}$ \\
\hline metolachlor & Pennant $^{\circledR}$ \\
\hline metsulfuron & $\begin{array}{l}\text { Manor }^{\circledR} \\
\text { Blade }^{\circledR}\end{array}$ \\
\hline MSMA & Many brands \\
\hline oryzalin & Surflan $^{\circledR}$ \\
\hline pendimethalin & $\begin{array}{l}\text { Pendulum }^{\circledR} \\
\text { Pre-M }^{\circledR} \\
\text { Turf Weedgrass Control }^{\circledR} \\
\text { Halts Crabgrass Preventer }^{\circledR}\end{array}$ \\
\hline
\end{tabular}


Table 2. Herbicide Common and Brand names

\begin{tabular}{|c|c|}
\hline Common Name & Brand Name \\
\hline Prodiamine & Sam's Choice Crabgrass Preventer ${ }^{\circledR}$ \\
\hline sethoxydim & Vantage $\mathrm{T} / \mathrm{O}^{\circledR}$ \\
\hline simazine & Princep $^{\circledR}$ \\
\hline triclopyr & Ortho Brush-B-Gon ${ }^{\circledR}$ \\
\hline 2,4-D + dicamba + MCPP, MCPP, and/or 2,4-DP & Many brands \\
\hline 2,4-D + MCPP + dicamba + carfentrazone & $\begin{array}{l}\text { SpeedZone for St. Augustinegrass }{ }^{\circledR} \\
\text { SpeedZone }^{\circledR}\end{array}$ \\
\hline MCPA + MCPP +dicamba + carfentrazone & SpeedZone ${ }^{\circledR}$ \\
\hline sethoxydim & Vantage $\mathrm{T} / \mathrm{O}^{\circledR}$ \\
\hline
\end{tabular}

